\title{
Immunoglobulins on the Surface of Lymphocytes
}

\author{
IV. DISTRIBUTION IN HYPOGAMMAGLOBULINEMIA, CELLULAR \\ IMMUNE DEFICIENCY, AND CHRONIC LYMPHATIC LEUKEMIA
}

\author{
Howard M. Grey, Enrique Rabeilino, and Bernard Pirofsky \\ From the Department of Allergy and Clinical Immunology, National Jewish \\ Hospital and Research Center, Denver, Colorado 80206, and University of \\ Oregon Medical School, Portland, Oregon 97201
}

\begin{abstract}
A B S TRACT The distribution of peripheral blood lymphocytes that contain surface Ig has been studied by means of immunofluorescence in humans. Normal individuals, individuals with sex-linked and acquired agammaglobulinemia, selective IgA deficiency, cellular immune deficiencies, and individuals with chronic lymphatic leukemia (CLL) were studied. Approximately $28 \%$ of the peripheral blood lymphocytes from normal individuals contained surface Ig. On an average $15 \%$ contained IgG, $6 \%, \operatorname{IgA}$, and $8 \%, \operatorname{IgM}$; and the kappa: lambda ratio was $2: 1$. Lymphocytes from patients with CLL appeared to be "monoclonal" in that the cells from a given individual had a single $\mathrm{Ig}$ associated with them (e.g., kappa IgM). In three-quarters of the cases the $\mathrm{H}$ chain class was $\operatorname{IgM}$; in the remaining onequarter no $\mathrm{H}$ chain could be detected on the cell surface. The $\mathrm{L}$ chain class was kappa in 12 cases and lambda in 8. Four patients with sex-linked agammaglobulinemia and one with "acquired" agammaglobulinemia had markedly decreased numbers of cells with surface Ig $(0-4 \%)$. In contrast, the three patients with selective IgA deficiency and no detectable serum IgA contained normal numbers of cells $(6-8 \%)$ with surface $\operatorname{IgA}$. Five patients with cellular deficiency states, including two with Wiskott-Aldrich syndrome, contained a normal or low percentage of cells with surface Ig.
\end{abstract}

\section{INTRODUCTION}

Small lymphocytes have been shown to have immunoglobulin-like molecules on their cell surface. The first

This work was presented in part at the Annual Meeting of the American Society for Clinical Investigation, May 1971, Atlantic City, N. J.

Received for publication 24 May 1971 and in revised form 6 July 1971. indirect demonstration of this phenomenon was that of Sell and Gell (1) who used a variety of anti-immunoglobulin antisera to stimulate blast transformation of rabbit peripheral blood lymphocytes. Subsequently, direct demonstration of immunoglobulin $(\mathrm{Ig})^{1}$ molecules by radioiodinated and fluorescein-conjugated anti-Ig antisera has been possible in mice, rabbits, and chickens (2-5). The source of lymphocytes with surface Ig has been shown to be the bone marrow (or bursa of Fabricius in the chicken [5]) and the source of the cells which lacks Ig to be the thymus (6). The purpose of the present report is to characterize the surface immunoglobulins in normal human blood and to determine any deviations from the normal distribution that might be encountered in certain immunologic deficiency diseases and lymphoproliferative disorders in order to gain information regarding the origin of the cellular dysfunction (i.e., thymus or bone marrow). The specific disease entities investigated were sex-linked and acquired hypogammaglobulinemia, selective $\operatorname{IgA}$ deficiency, cellular immune deficiency states, and chronic lymphatic leukemia.

\section{METHODS}

Antisera. Rabbit anti-immunoglobulin antisera to the major heavy-chain classes, $\operatorname{IgG}$, IgA, and $\operatorname{IgM}$, and the two light-chain types, kappa and lambda, were produced in rabbits by immunization with normal IgG and paraproteins of the $\operatorname{IgA}$ and $\operatorname{IgM}$ class, respectively. Antisera to kappa and lambda light chains were prepared in rabbits immunized to Bence Jones proteins of the appropriate type. The antisera were rendered monospecific by immunoadsorption with Ig coupled to cyanogen bromide-activated

${ }^{1}$ Abbreviations used in this paper: $\mathrm{B}$, bone marrow-derived (lymphocytes); CLL, chronic lymphatic leukemia; HBSS, Hanks' balanced salt solution; Ig, immunoglobulin; $\mathrm{T}$, thymus-derived (cells). 
Sepharose columns (7). IgG antisera were adsorbed with $\mathrm{F}\left(\mathrm{ab}^{\prime}\right)_{2} ; \operatorname{IgA}$ and $\operatorname{IgM}$ with normal IgG and cord serum; kappa and lambda antisera with IgG myeloma proteins of the opposite types. After immunoadsorption, the IgG fraction of the rabbit antisera prepared by DEAE-cellulose chromatography were fluoresceinated as previously described and further fractionated on DEAE-cellulose (3). Conjugated antisera having fluorescein:protein ratios varying between 2: and 3:1 were used for direct immunofluorescent identification of immunoglobulins on the surface of lymphocytes.

Lymphocyte preparations. Cell suspensions of spleen and lymph nodes were made by gently pressuring the minced organ through a stainless steel wire mesh into tissue culture dishes containing Hanks' balanced salt solution (HBSS). Peripheral blood lymphocytes were prepared by centrifugation on a Ficoll (Pharmacia Fine Chemicals, Inc., Piscataway, N. J.) gradient (8) or a modification of the Ficoll-Triosil (sodium metrizoate) method (9) using $\mathrm{Hy}-$ paque (sodium diatrizoate; Winthrop Laboratories, New York) instead of Triosil. In most cases, the blood was allowed to sediment in 3\% dextran (Pharmacia Fine Chemicals, Inc.), and the white cell-enriched supernatant was used for the Ficoll-Hypaque centrifugation rather than whole blood. The preparations prepared from peripheral blood were routinely $85-95 \%$ lymphocytes. The yield of $1 \mathrm{ym}-$ phocytes was generally in the range of $70 \%$. Spleen and lymph node preparations were contaminated with approximately $30 \%$ macrophages.

Radial immunodiffusion. Quantitation of serum immunoglobulin levels was performed as previously described (10). Paraproteins at known concentrations were used as standards. Quantitation of the amounts of kappa and lambda in serum was performed on serum which was reduced with $0.1 \mathrm{M}$ 2-mercaptoethanol for $1 \mathrm{hr}$ at room temperature before filling the wells.

Immunofluorescent staining. Cells were washed three times in HBSS before being reacted with fluoresceinated antisera. To portions of $1-10 \times 10^{\circ}$ cells in about $0.1 \mathrm{ml}$ was added $0.1 \mathrm{ml}$ of fluoresceinated antisera (at a concentration of $1-3 \mathrm{mg} / \mathrm{ml}$ ), and the reaction mixture was incubated at room temperature for $30 \mathrm{~min}$ with occasional gentle shaking. Cells were then washed three times with HBSS and resuspended in $0.5 \mathrm{ml}$ of the same buffer. A drop of the cell suspension was placed on a slide, overlayed with a cover slip, and the edges sealed with melted paraffin. The immunofluorescence was examined with a Zeiss ultraviolet microscope equipped with an Ossran HBD 200 mercury arc lamp as a light source. Total cell numbers and cell types were evaluated in the absence of a barrier filter.

\section{RESULTS}

Peripheral blood lymphocytes with surface Ig from normal individuals. Lymphocytes from the peripheral blood of 10 normal individuals were examined for the presence of surface immunoglobulins. The appearance of lymphocytes with and without detectable surface $\mathrm{Ig}$ is illustrated in Fig. 1. The positive cells had a speckled distribution of $\mathrm{Ig}$ on their surface; the crescentic pattern observed with great frequency in the mouse (3) was much less apparent in human lymphocytes. The data obtained for different Ig classes on the 10 normal
TABLE I

Surface Ig on Normal Human Peripheral Blood Lymphocytes

\begin{tabular}{lllrrr}
\hline Patient & G & A & M & K & $\lambda$ \\
\hline & & & $\%$ & & \\
Abe. & 14 & 3 & 7 & 13 & 8 \\
Aug. & 14 & 8 & 7 & 17 & 11 \\
Sta. & 19 & 5 & 9 & 14 & 14 \\
Gua. & 12 & 6 & 8 & 18 & 9 \\
Bit. & 12 & 4 & 11 & 22 & 11 \\
Gre. & 19 & 4 & 8 & 22 & 11 \\
Ore. & 11 & 3 & 3 & 12 & 2 \\
Har. & 15 & 7 & 9 & 21 & 11 \\
Stu. & 14 & 8 & 11 & 24 & 8 \\
All. & 15 & 7 & 7 & 23 & 8 \\
Avg. & 14.5 & 5.5 & 8.0 & 18.6 & 9.3 \\
\hline
\end{tabular}

individuals studied, ranging in age from 8 to 40 , are given in Table I. A range of $11-19 \%$ of cells stained with IgG-specific antiserum, 3-8\% with $\operatorname{IgA}, 3-11 \%$ with $\operatorname{IgM}, 12-24 \%$ with kappa, and $2-14 \%$ with lambda. The average percentage of positive cells is shown at the bottom of the Table. On average, $28 \%$ of lymphocytes stained with kappa or lambda antisera. When a polyvalent antiserum was used instead of class specific antisera, approximately the same percentage of cells stained for Ig as the sum of the positive cells staining for $\operatorname{IgG}, \operatorname{IgA}$, and IgM, or kappa and lambda light chains. In all cases, the staining could be shown to be specific for the immunoglobulin class that was tested by absorption of the antisera before staining with different Ig preparations including the Ig for which the antiserum had specificity. Only if the nonspecific absorption had no effect and the specific ab-

TABLE II

Surface Ig on Human Lymphocytes

\begin{tabular}{|c|c|c|c|c|c|c|}
\hline \multirow[b]{2}{*}{ Organ } & \multirow[b]{2}{*}{ Patient } & \multicolumn{5}{|c|}{ Spleen and lymph nodes } \\
\hline & & G & $\mathbf{A}$ & $\mathbf{M}$ & $\mathbf{K}$ & $\lambda$ \\
\hline & & & & $\%$ & & \\
\hline \multirow[t]{7}{*}{ Spleen } & Onu. & 7 & 2 & 5 & 14 & 5 \\
\hline & Gol. & 20 & 3 & 11 & 27 & 8 \\
\hline & Hec. & 15 & 6 & 11 & 28 & 9 \\
\hline & How. & 25 & 8 & 17 & 43 & 10 \\
\hline & Vec. & 12 & 9 & 10 & 23 & 5 \\
\hline & Cam. & 9 & 5 & 11 & 20 & 9 \\
\hline & Avg. & 14.7 & 5.5 & 10.8 & 25.8 & 7.7 \\
\hline \multirow[t]{2}{*}{ Lymph node } & How. & 9 & 8 & 15 & 20 & 10 \\
\hline & Vec. & 7 & 3 & 1 & 10 & 3 \\
\hline \multirow[t]{2}{*}{ Thymus } & Mic. & —* & $\mathrm{ND} \ddagger$ & ND & - & ND \\
\hline & Cal. & - & - & - & - & - \\
\hline
\end{tabular}

* Indicates less than $1 \%$.

$\mp N D$, not determined due to insufficient material. 


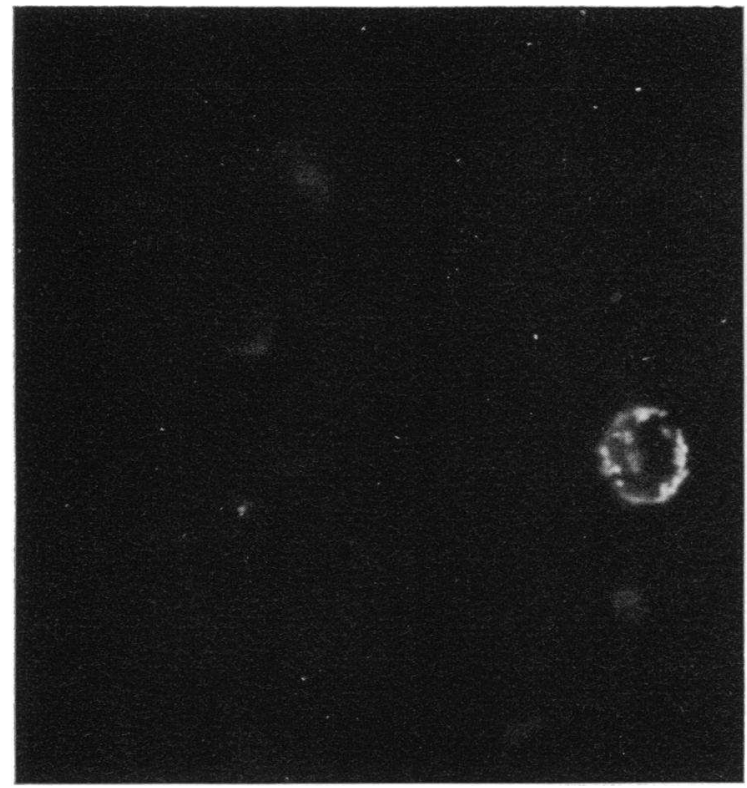

FIGURE 1 Immunofluorescent appearance of cells containing surface Ig. Normal peripheral blood lymphocytes were stained with fluoresceinated anti-IgM. Three positive cells and several negative cells are illustrated. $\times 1200$.

sorption removed the reactivity were the antisera considered specific.

Surface immunoglobulin on the lymphocytes of spleen, lymph node, and thymus. Spleen, lymph nodes, and thymus were obtained from autopsy material or patients that had undergone splenectomy for Hodgkin's disease. Only those spleens that showed no abnormal histology were included in the study. The data shown in Table II indicate that an average of $33 \%$ of human spleen cells contained detectable amounts of surface immunoglobulin and that the distribution of the different immunoglobulin classes was similar to that observed in peripheral blood. Only two lymph node preparations were available for examination, so that no conclusions can
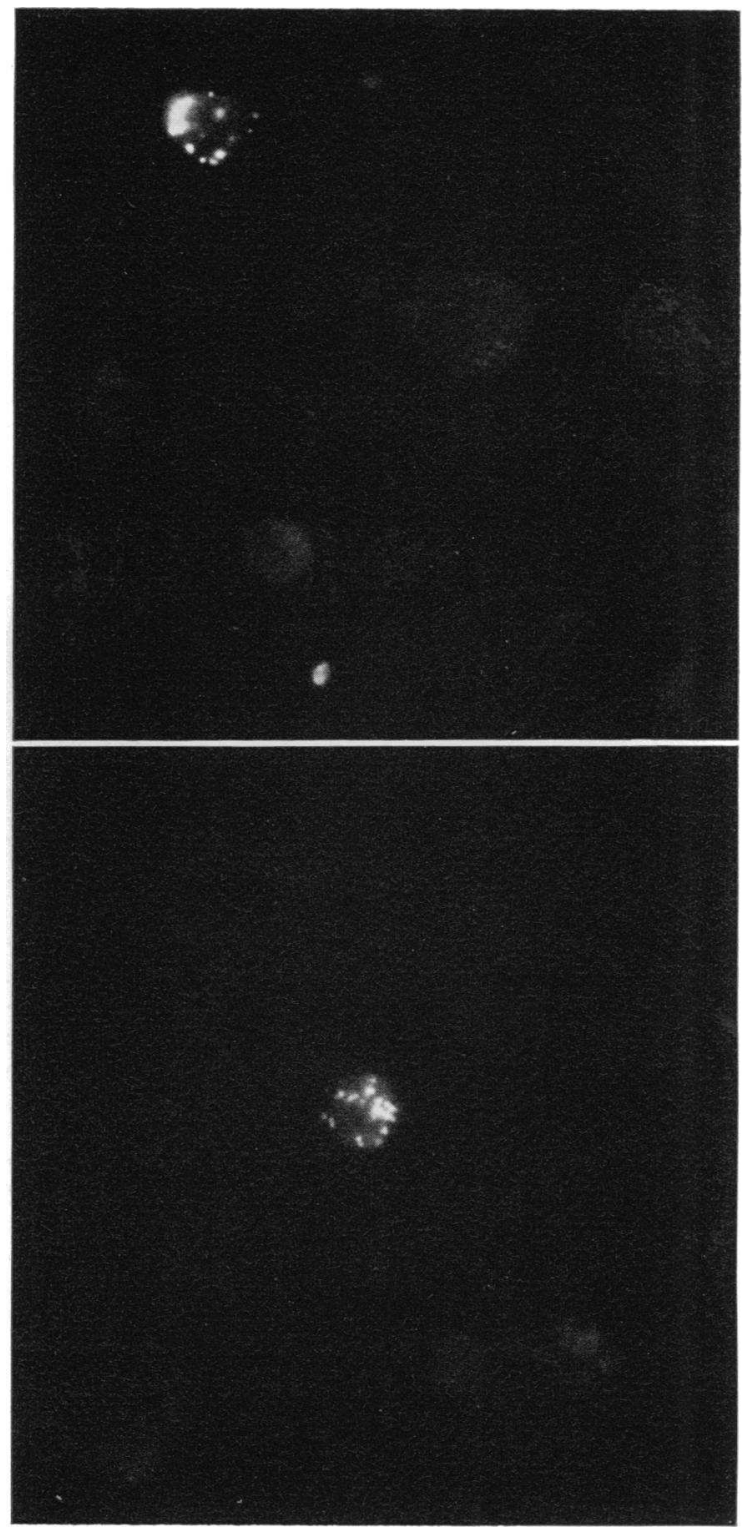

be drawn regarding any possible differences in distribution of lymphocytes with surface Ig between this material and peripheral blood. The virtual absence of surface Ig-containing cells in the thymus is in keeping with data obtained in mice, chickens, and rabbits (2-5).

Surface immunoglobulin on human lymphocytes from patients with chronic lymphatic leukemia. The peripheral blood of a total of 20 patients with chronic lymphatic leukemia was examined for surface immunoglobulin on their lymphocytes. In most instances it was possible also to examine the serum immunoglobulin levels of these patients. The results of these studies are shown in Table III. The data were clearly divisible into three antigenic classifications. With two exceptions the 
TABLE III

Surface Ig on Human Lymphocytes

\begin{tabular}{|c|c|c|c|c|c|c|c|c|c|c|c|}
\hline \multirow[b]{3}{*}{ Group } & \multirow[b]{3}{*}{ Patient } & \multicolumn{10}{|c|}{ Chronic lymphocytic leukemia } \\
\hline & & \multicolumn{5}{|c|}{ Surface Ig } & \multicolumn{5}{|c|}{ Serum Ig } \\
\hline & & G & A & $\mathbf{M}$ & $\mathrm{K}$ & $\lambda$ & G & A & M & $\mathrm{K}$ & $\lambda$ \\
\hline \multirow[t]{8}{*}{1} & Mar. & —* & - & $\begin{array}{l}\% \\
76\end{array}$ & 84 & 一 & 8.0 & 0 & $\begin{array}{l}m g / m l \\
1.5\end{array}$ & ND $\ddagger$ & ND $\ddagger$ \\
\hline & Smi. & - & - & 90 & 70 & - & & & & & \\
\hline & Fol. & 6 & 5 & 52 & 90 & 3 & 9.6 & 1.9 & 0.3 & 4.8 & 1.5 \\
\hline & Hin. & 3 & - & 30 & 80 & - & 3.3 & 0.9 & 0.3 & 5.4 & 1.4 \\
\hline & Ves. & 13 & 10 & 30 & 40 & 7 & 13.7 & 1.3 & 1.1 & 7.8 & 2.5 \\
\hline & Wal. & - & - & 63 & 60 & - & 15.6 & 2.8 & 1.1 & 24.0 & 2.5 \\
\hline & Gre. & - & - & 76 & 96 & - & & & & & \\
\hline & Swa. & - & - & 95 & 100 & - & 6.0 & 1.0 & 0.5 & 3.3 & 1.3 \\
\hline \multirow[t]{7}{*}{2} & Kos. & - & - & 80 & - & 40 & & & & & \\
\hline & Kau. & 4 & - & 40 & - & 50 & & & & & \\
\hline & Lin. & - & - & 95 & - & 100 & 2.6 & 0.2 & 0.3 & 1.4 & 0.5 \\
\hline & Oia. & - & - & 90 & - & 90 & 5.8 & 0.3 & 0.3 & 2.8 & 1.0 \\
\hline & Val. & - & - & 100 & - & 40 & 10.8 & 0.8 & 1.2 & 6.9 & 2.1 \\
\hline & Pie. & - & - & 100 & - & 90 & 4.8 & 0.6 & 0.3 & 3.0 & 0.8 \\
\hline & Rud. & - & - & 40 & - & 75 & & & & & \\
\hline \multirow[t]{5}{*}{3} & Gar. & - & - & 2 & 77 & - & 9.8 & 0.5 & 0.3 & 6.8 & 1.7 \\
\hline & Hay. & - & - & - & 61 & - & 11.4 & 0.5 & 0.2 & 4.2 & 3.9 \\
\hline & Ste. & 2 & - & - & 60 & - & 4.8 & 0.5 & 0.2 & 2.0 & 0.7 \\
\hline & Lar. & 2 & - & 1 & - & 100 & 12.0 & 1.4 & 0.3 & 11.1 & 2.1 \\
\hline & Zie & - & - & - & 42 & - & 8.0 & 0 & 0.2 & 4.8 & 0.7 \\
\hline
\end{tabular}

* Indicates less than $1 \%$.

$\ddagger N D$, not determined.

cells from these patients had a restricted distribution of immunoglobulins on their surface since in contrast with the findings with normal blood in which all of the major Ig classes were represented, only one heavychain class and one light-chain type were seen on the cells of an individual patient with chronic lymphatic leukemia. In groups 1 and 2 the heavy-chain class that was represented in a high percentage of the cells from any individual was IgM. In group 1 the light-chain type was kappa; in group 2 the light-chain type was lambda. In group 3 none of the major heavy-chain classes were identified in more than a very small percentage of the cells whereas a large proportion of the cells had either kappa or lambda light chains on the surface. In two cases (Fol. and Ves.), a significant percentage of IgG- and IgA-containing cells were also observed, and in the case of Ves., a significant number of lambda chains as well as kappa chains were seen. It may be significant that due to chemotherapy, the lymphocyte counts in both of these cases were under 10,000 . It is quite clear from these data that in many instances not all of the cells contained surface Ig, the percentage of positive cells ranging from 30 to $100 \%$. Also, there was no strict correlation between the percentage of cells that contained light-chain determinants and those that contained heavy-chain determinants. In some instances only half the cells that contained heavy-chain determinants contained detectable light-chain determinants and vice versa. With one exception (Wal.), there was no evidence that a paraprotein of type similar to that present on the surface of the lymphocytes was present in the serum. Kappa: lambda ratios for the patients containing kappa chains on their lymphocytes were no different on average from the kappa:lambda ratios from patients containing lambda chains on their lymphocytes (3.18:1 vs. 3.16:1). Also, there was no elevation of the IgM levels in any of the cases studied, and in no case was a paraprotein peak evident on cellulose acetate electrophoresis. The Ig levels in most of these patients were depressed, and the depression in $\operatorname{Ig} M$ was in general similar to that observed in $\operatorname{IgG}$ and $\operatorname{IgA}$. The patients studied represented a spectrum of disease activity from remission to very active disease. There was no correlation between the degree of activity (as measured by peripheral lymphocyte count, splenomegaly, or lymphadenopathy) and the results ex- 
TABLE IV

Clinical and Laboratory Features of Patients with Humoral and/or Cellular Deficiency States

\begin{tabular}{|c|c|c|c|c|c|c|c|}
\hline Patient & Age & Sex & $\begin{array}{l}\text { Age at } \\
\text { onset }\end{array}$ & $\begin{array}{l}\text { Serum } \\
\text { Ig* }\end{array}$ & $\begin{array}{l}\text { Humoral } \\
\text { immunity }\end{array}$ & $\begin{array}{l}\text { Cellular } \\
\text { immunity }\end{array}$ & Clinical features \\
\hline Cow. W. & $\begin{array}{l}y r \\
15\end{array}$ & $\mathbf{M}$ & $\begin{array}{c}y r \\
1\end{array}$ & GAM $\downarrow$ & Absent & Intact & $\begin{array}{l}\text { Recurrent pyogenic infections. Male } \\
\text { sibling (R. Cow.) has agammaglobu- } \\
\text { linemia. }\end{array}$ \\
\hline Cow. $\mathbf{R}$. & 12 & $\mathbf{M}$ & 1 & GAM $\downarrow$ & Absent & Intact & $\begin{array}{l}\text { Recurrent pyogenic infections. Male } \\
\text { sibling (W. Cow.) has agammaglobu- } \\
\text { linemia. }\end{array}$ \\
\hline Car. & 17 & $\mathbf{M}$ & $1 / 2$ & $\mathrm{GAM} \downarrow$ & Absent & Intact & $\begin{array}{l}\text { Recurrent pyogenic infections. One male } \\
\text { sibling had agammaglobulinemia; died } \\
\text { of meningitis. One male sibling died at } \\
1 \mathrm{yr} \text { of sepsis. }\end{array}$ \\
\hline Ols. & 16 & $\mathbf{M}$ & 2 & GAM $\downarrow$ & Absent & Intact & Recurrent infections, G. I. malabsorption. \\
\hline Lan. & 32 & $\mathrm{~F}$ & 29 & GAM $\downarrow$ & Absent & Intact & $\begin{array}{l}\text { Recurrent sinusitis and pneumonitis for } \\
\text { past } 3 \text { yr. Daughter has low Ig levels. }\end{array}$ \\
\hline Van. & 7 & $\mathbf{M}$ & 2 & $\begin{array}{l}\mathrm{G} \rightarrow \\
\mathrm{AM} \downarrow\end{array}$ & Intact & Intact & Chronic diarrhea since age 2. \\
\hline Kru. & 20 & $\mathrm{~F}$ & 16 & $\begin{array}{l}\mathrm{GM} \rightarrow \\
\mathrm{A} \downarrow\end{array}$ & Intact & Intact & $\begin{array}{l}\text { Systemic lupus erythematosus, + L. E. } \\
\text { prep, + Coombs test, + rheumatoid } \\
\text { factor. }\end{array}$ \\
\hline Wol. & 2 & $\mathbf{M}$ & At birth & $\begin{array}{l}\mathrm{GM} \rightarrow \\
\mathrm{A} \downarrow\end{array}$ & Intact & Intact & $\begin{array}{l}\text { Congenital rubella, lymphadenopathy, } \\
\text { splenomegaly; failure to thrive. }\end{array}$ \\
\hline The. W. & 6 & $\mathbf{M}$ & $1 \mathrm{wk}$ & $\begin{array}{l}\mathrm{GM} \rightarrow \\
\mathrm{A} \downarrow\end{array}$ & Intact & $\begin{array}{l}\text { Skin tests neg. to bacterial, } \\
\text { fungal antigens and } \\
\text { DNCB; skin homograft } \\
\text { intact } 2+\text { yr.f }\end{array}$ & $\begin{array}{l}\text { Mucocutaneous candidiasis, juvenile } \\
\text { diabetes; recurrent infections, failure } \\
\text { to thrive. Received "Transfer factor" } \\
\text { after this study. }\end{array}$ \\
\hline The. P. & 9 & $\mathrm{~F}$ & $1 \mathrm{wk}$ & $\underset{\mathrm{M} \uparrow}{\mathrm{GA}} \rightarrow$ & Intact & $\begin{array}{l}\text { Neg. to all skin tests; skin } \\
\text { homograft rejected } \\
15 \text { days. }\end{array}$ & $\begin{array}{l}\text { Mucocutaneous candidiasis, recurrent } \\
\text { infections, failure to thrive. }\end{array}$ \\
\hline Rob. & 8 & $\mathbf{M}$ & 1 & $\begin{array}{l}\mathrm{G} \rightarrow \\
\mathrm{A} \uparrow \\
\mathrm{M} \downarrow\end{array}$ & $\begin{array}{l}\text { Intact (carbohydrate } \\
\text { antigens not } \\
\text { tested) }\end{array}$ & Negative to all skin tests. & $\begin{array}{l}\text { Eczema, thrombocytopenia, recurrent } \\
\text { infections. Reported in (11). }\end{array}$ \\
\hline Per. & 11 & $\mathbf{M}$ & 1 & $\begin{array}{l}\mathrm{GA} \rightarrow \\
\mathrm{M} \downarrow\end{array}$ & $\begin{array}{l}\text { Anti-protein intact; } \\
\text { anticarbohydrate } \\
\text { deficient }\end{array}$ & Negative to all skin tests. & $\begin{array}{l}\text { Eczema, thrombocytopenia, received } \\
\text { "Transfer factor" before study- } \\
\text { reported in (12). }\end{array}$ \\
\hline Mil. & 19 & $\mathrm{~F}$ & At birth & $\mathrm{GAM} \rightarrow$ & Intact & $\begin{array}{l}\text { Negative to all skin tests; } \\
\text { skin graft intact } 1+\text { yr. }\end{array}$ & $\begin{array}{l}\text { Mucocutaneous and systemic candidiasis, } \\
\text { juvenile diabetes, recurrent infections, } \\
\text { Coombs pos. hemolytic anemia; } \\
\text { retarded puberty. }\end{array}$ \\
\hline
\end{tabular}

$* \rightarrow$, normal Ig levels; $\downarrow$, below normal Ig levels; $\uparrow$, above normal Ig levels.

¥ Antigens tested for included : tuberculin, candida, mumps, histoplasmin, blastomycin, coccidiomycin, and trichophyton.

pressed in Table III with the exception noted above that two patients with low lymphocyte counts due to chemotherapy had some degree of heterogeneity in their surface Ig pattern. We conclude from these experiments that in the vast majority of cases of chronic lymphatic leukemia the leukemia represents what would appear to be a monoclonal expression of a given cell type which in most cases contains IgM on the surface, either of kappa or lambda type, and in a few cases would appear to contain only light-chain determinants.

Humoral immune deficiency states. Four cases of Bruton type agammaglobulinemia and one case of "acquired" agammaglobulinemia in a $32 \mathrm{yr}$ old female were examined for surface immunoglobulins on periph- eral blood lymphocytes. Also, three cases of selective IgA deficiency were examined (see Table IV). All five individuals with agammaglobulinemia had no detectable serum IgA and IgM and low but detectable amounts of IgG in part due to their receiving gamma globulin therapy (Table V). All of these patients had much lower levels of IgG before the institution of treatment. All patients with Bruton type agammaglobulinemia had a very low number of peripheral blood lymphocytes that contained detectable surface immunoglobulin. In three cases, the total number of lymphocytes that were positive for surface immunoglobulin were $1 \%$ or lower. In the fourth case, $2 \%$ of the peripheral lymphocytes were positive. In the one case of "acquired" agamma- 
TABLE V

Humoral Immune Deficiency Diseases

\begin{tabular}{|c|c|c|c|c|c|c|c|c|}
\hline \multirow{2}{*}{$\begin{array}{c}\text { Type of } \\
\text { deficiency }\end{array}$} & \multirow[b]{2}{*}{ Patient } & \multirow[b]{2}{*}{ Total } & \multicolumn{3}{|c|}{ Surface Ig } & \multicolumn{3}{|c|}{ Serum Ig } \\
\hline & & & G & A & $\mathbf{M}$ & G & $\mathbf{A}$ & $\mathbf{M}$ \\
\hline & & & \multicolumn{3}{|c|}{$\%$} & \multicolumn{3}{|c|}{$m g / m l$} \\
\hline Bruton & Cow. W. & —* & - & - & - & 0.12 & $0 \ddagger$ & 0 \\
\hline Bruton & Cow. R. & 1 & - & - & - & 0.66 & 0 & 0 \\
\hline Bruton & Car. & 1 & - & - & - & 1.8 & 0 & 0 \\
\hline Bruton & Ols. & 2 & - & - & - & 1.6 & 0 & 0 \\
\hline Acquired & Lan. & 4 & 1 & 2 & 2 & 0.8 & 0 & 0 \\
\hline Selective IgA & Van. G. & & 13 & 6 & 9 & 13.6 & 0 & 0.22 \\
\hline Selective IgA & Kru. & & 14 & 8 & 10 & 34.4 & 0 & 1.15 \\
\hline Selective IgA & Wol. & & 10 & 7 & 16 & 11.8 & 0 & 0.59 \\
\hline
\end{tabular}

* Signifies less than $1 \%$ of positive cells.

$\ddagger 0$ indicates not detectable by techniques used. For $\operatorname{IgA}$ and $\operatorname{Ig} M$, the lower limit of detection is $0.01 \mathrm{mg} / \mathrm{ml}$.

globulinemia there was a slightly greater number of positive lymphocytes; however, the number of positive lymphocytes was still markedly reduced from the average present in normal peripheral blood $(25-30 \%)$. In the three patients with selective IgA deficiency, there were normal numbers of cells containing all immunoglobulins, including IgA, despite the fact that there was no detectable $\operatorname{IgA}$ in the serum of these three individuals.

Cellular immune deficiency states. The blood from five children with cellular immune deficiency disease was examined (Table VI). Two cases had well documented Wiskott-Aldrich syndromes (Rob. and Per.) which have been previously recorded $(11,12)$, and three cases were of unclassified cellular deficiency states characterized by negative skin reactions to a variety of bacterial antigens, a prolonged survival of skin homograft, and a history of chronic infections. In all cases, either normal numbers of peripheral blood lymphocytes with surface immunoglobulins were seen or a moderate to marked decrease in these cells (Rob.). In no case was there any elevation in the percentage of cells that contained surface immunoglobulins.

\section{DISCUSSION}

Immunoglobulins have been identified on the surface of small lymphocytes in all vertebrate species that have been investigated using techniques similar to those described in the present study. In all of these species there are two clearly distinguishable lymphocyte populations: those that have detectable Ig on their surface and a population of cells that lacks detectable Ig. Quantitative studies indicated that $50-150,000$ molecules of $\mathrm{Ig}$ are present on those cells that contain detectable surface Ig, whereas 0-1000 molecules per cell may be present on those cells which lack detectable surface Ig $(3,6)$.

The source of those cells that contain detectable immunoglobulin and those that do not, has been extensively studied in the mouse and chicken. Studies by Raff and associates $(2,13)$ indicated that there was an inverse relationship between the presence of immunoglobulin on the surface of cells and the presence of theta antigen, a marker for thymus-derived cells, in that peripheral blood and lymph nodes were rich in cells containing theta antigen and relatively poor in cells that contained surface Ig, whereas in the spleen the reverse situation held. This observation led to the suggestion that surface Ig-containing cells were derived from the bone marrow and the negative cells from the thymus. These studies were extended in the mouse in a study using neonatal and adult thymectomized animals reconstituted with bone marrow and/or thymus (6). When the spleens of neonatally thymectomized animals or adult thymectomized; lethally irradiated, bone marrow- transplanted animals were examined, a very high percentage of Ig-positive lymphocytes (in many cases approaching $100 \%$ ) were observed. These results indicated that the Ig-containing cells were, to a large extent, derived from

TABLE VI

Cellular Immune Deficiency Diseases

\begin{tabular}{|c|c|c|c|c|c|c|c|c|}
\hline \multirow[b]{2}{*}{ Patient } & \multicolumn{5}{|c|}{ Surface Ig } & \multicolumn{3}{|c|}{ Serum Ig } \\
\hline & G & $\mathbf{A}$ & $\mathbf{M}$ & $\mathbf{K}$ & $\lambda$ & G & $\mathbf{A}$ & $\mathbf{M}$ \\
\hline & \multicolumn{5}{|c|}{$\%$} & \multicolumn{3}{|c|}{$m g / m l$} \\
\hline The. P. & 8 & 12 & 17 & 24 & 11 & 20.1 & 2.4 & 2.3 \\
\hline The. W. & 5 & 7 & 11 & 11 & 10 & 12.0 & 0 & 0.5 \\
\hline Mil. & 20 & 1 & 8 & 23 & ND & 19.0 & 0.9 & 0.9 \\
\hline Rob. & 3 & 2 & 2 & 3 & 1 & 14.1 & 4.7 & 0.3 \\
\hline Per. & 15 & 10 & 10 & 15 & ND & 17.7 & 2.4 & 0.6 \\
\hline
\end{tabular}


bone marrow. When syngeneic bone marrow and $F_{1}$ thymus were transplanted into lethally irradiated thymectomized animals, it was possible to demonstrate by use of an $\mathrm{H} 2$ antiserum that the negative cell population was derived from the transplanted $F_{1}$ thymus. In experiments in the chicken involving neonatal bursectomy and irradiation, it was similarly shown that the bursa of Fabricius was the major source of the positive cell population since neonatal bursectomy reduced the per cent of positive cells in the peripheral blood from $45 \%$ to $2-9 \%$ (5).

These animal experiments clearly indicate that the bone marrow (or the bursa of Fabricius in the chicken) is the major source of those cells which contain detectable quantities of surface immunoglobulins and that the thymus is the source of those cells which lack detectable surface immunoglobulins. For this reason surface Ig can be reasonably used as a marker for bone marrow-derived (B) lymphocytes and the lack of surface $\mathrm{Ig}$ as an indicator for thymus-derived $(\mathrm{T})$ cells. The results of the present study will be discussed on the assumption that this premise is basically correct.

Three groups of patients with lymphocyte-related disorders were examined for the presence of surface Ig-containing cells: $(a)$ patients with hypogammaglobulinemia either involving all Ig classes or only $\operatorname{IgA} ;(b)$ patients with defective cellular immunity; and $(c)$ patients with chronic lymphatic leukemia. The four patients with sexlinked hypogammaglobulinemia who were examined, formed a rather uniform group with respect to the presence of surface Ig-containing cells. These cells were found in very low numbers in the peripheral blood of all patients examined. The straightforward interpretation of these data would be that this disease is characterized by a generalized lack of $B$ lymphocytes in the peripheral blood. This interpretation is supported by the fact that $B$ cells have been shown to be the precursor of antibodyforming cells which are absent in hypogammaglobulinemics. Whether the cellular defect which leads to the absence of B cells in the periphery is due to a lack of the appropriate stem cell or whether the defect lies in the maturation of a stem cell to a differentiated B cell with surface Ig, cannot be answered from our data. The data that were obtained from three patients with selective $\operatorname{IgA}$ deficiency were in contrast with those obtained with sex-linked agammaglobulinemia (as well as the one patient with acquired agammaglobulinemia). Despite the complete absence of IgA in the serum of these individuals, a normal percentage of circulating lymphocytes contained surface IgA. These data are interpreted as indicating that differentiated $\mathrm{B}$ cells of the IgA class are present in the peripheral blood of these individuals, but the immunologic defect lies in the maturation process involving the conversion of a $\mathrm{B}$ precursor cell into an active antibody-producing plasma cell. It is of interest that the presence of surface IgA-containing lymphocytes in IgA-deficient individuals was suggested by the studies of Oppenheim, Rogentine, and Terry, (14) who found that anti-IgA antiserum induced the same degree of blast transformation in IgA-deficient individuals as in normals.

The results obtained with the lymphocytes from patients with cellular immune defects of the WiskottAldrich type are most easily explained in a manner similar to the explanation given for the presence of $\operatorname{IgA} \mathrm{B}$ cells in IgA-deficient individuals. The presence of normal or increased numbers of cells which lack surface Ig indicates that there is no deficiency in the number of $T$ cells present in these individuals and that the defect presumably lies in the expression of the $\mathrm{T}$ cell function (i.e., delayed hypersensitivity and homograft rejection). This is in keeping with previous morphological studies which indicated normal thymic development and for a time at least normal development of the thymus-dependent areas of peripheral lymphoid tissue in patients with WiskottAldrich syndrome (11). Other forms of cellular immune deficiency such as Nezelof's and Di George's syndromes in which there is greatly abnormal thymic development may be expected to show a picture analagous to the Bruton hypogammaglobulinemia in which there is an absence of the $T$ cell population rather than a malfunction of it.

From the examination of peripheral blood lymphocytes from 20 patients with chronic lymphatic leukemia (CLL), a fairly clear-cut picture of a "monoclonal" expression of a single immunoglobulin class emerged. Either kappa or lambda light chains were expressed on any one individual's leukemic cells but with one exception there was no instance where appreciable amounts of both kappa and lambda were detected in a leukemic's peripheral blood lymphocytes. IgM was the major heavychain class that was identified in all of these patients and with two exceptions the only heavy-chain class. We also observed five cases in which only light chains could be detected by immunofluorescence. These results extend the recent observations of Klein and associates $(15,16)$ on a few cases of CLL and Burkitt lymphoma in which IgM was found on the surface of the leukemic and lymphoma cells. The present study together with those of Pernis (17) make a very striking association of $\operatorname{IgM}$ on the surface of CLL cells. The authors are aware of approximately 45 patients who have been studied, and in no case has any other heavy-chain class been found. These findings raise several interesting questions. First, there appears to be a restriction in the leukemic process to cells that contain surface immunoglobulin. Two possibilities exist for this findings: $(a)$ the bone marrowderived cells are the only lymphocytes susceptible to the 
leukemic process, and $(b)$ thymic-derived cells can be transformed into leukemic cells but in so doing, differentiate to produce detectable amounts of $\operatorname{IgM}$ on their surface. The further restriction of CLI. to cells expressing the IgM class is also very striking, and the same reasons can be invoked to explain the phenomenon as mentioned above viz., that only IgM-containing cells are susceptible to the leukemic process or part of the leukemic process involves a differentiation of the malignant cells to produce IgM. The finding of five leukemias in which only light chains were detectable on the lymphocyte surface makes an interesting analogy to the situation which occurs in multiple myeloma where occasionally one sees production of light chains in the absence of heavy chains with resultant Bence Jones proteinuria. In the case of lymphatic leukemia, since at present we are identifying these immunoglobulins solely by means of immunofluorescence, considerable caution should be exercised with regard to interpreting these data.

There were varying numbers of CLL lymphocytes in any individual case which lacked detectable immunoglobulin. The source of these cells is at present unknown; however, it would appear reasonable to suggest that a similar situation exists to that described in human cultured cell lines where just after mitosis during the early G1 phase of the cell cycle, no immunoglobulins are produced and that the cells in this phase of the cell cycle show no detectable immunoglobulins (18). The other possibility to explain the negative cells would be that they represent a background of normal thymic-derived cells.

Although the finding that CLL cells are restricted to a single light-chain and heavy-chain class is suggestive, it is not in itself sufficient proof that the surface Ig is "monoclonal." Some immunologic or chemical evidence of homogeneity in the variable region of the Ig must also be sought. To this end we are currently attempting to raise idiotypic antibodies to the surface immunoglobulin. If this proves to be successful, it would represent very strong evidence that the surface Ig in CLL is structurally homogeneous (19).

\section{ACKNOWLEDGMENTS}

The authors gratefully acknowledge the excellent technical assistance of Miss Patricia Hennessy. We also thank the following physicians for providing us with some of the blood samples: Doctors L. Spitler, P. Hamilton, C. August, R. Rothberg, W. Robinson, W. Hammond, P. Kohler, and E. Ellis.

This work was supported by research grants from the U. S. Public Health Service AI-09758 and the American Heart Association Grant 70-749.

\section{REFERENCES}

1. Sell, S., and P. G. H. Gell. 1965. Studies on rabbit lymphocytes in vitro. I. Stimulation of blast trans- formation with an antiallotype serum. J. Exp. Med. 122: 423.

2. Raff, M. C., M. Sternberg, and R. B. Taylor. 1970. Immunoglobulin determinants on the surface of mouse lymphoid cells. Nature (London). 225: 553.

3. Rabellino, E., S. Colon, H. M. Grey, and E. K. Unanuc. 1971. Immunoglobulins on the surface of lymphocytes. I. Distribution and quantitation. J. Exp. Med. 133: 156.

4. Pernis, B., L. Forni, and L. Amante. 1970. Immunoglobulin spots on the surface of rabbit lymphocytes. $J$. Exp. Med. 132: 1001.

5. Rabellino, E., and H. M. Grey. 1971. Immunoglobulins on the surface of lymphocytes. III. Bursal origin of surface immunoglobulins on chicken lymphocytes. $J$. Immunol. 106: 1418.

6. Unanue, E. R., H. M. Grey, E. Rabellino, P. Campbell, and J. Schmidtke. 1971. Immunoglobulins on the surface of lymphocytes. II. The bone marrow as the main source of lymphocytes with detectable surfacebound immunoglobulin. J. Exp. Med. 133: 1188.

7. Cuatrecasas, P., M. Wilcheck, and C. B. Anfinsen. 1968. Selective enzyme purification by affinity chromatography. Proc. Nat. Acad. Sci. U. S. A. 61: 636.

8. Noble, P. B., J. H. Cutts, and K. K. Carroll. 1968. Ficoll flotation for the separation of blood leukocyte types. Blood. 31: 66 .

9. Harris, R., and E. O. Ukaejiofo. 1969. Rapid preparation of lymphocytes for tissue typing. Lancet. 2: 327.

10. Mancini, G., A. O. Carbonara, and J. F. Heremans. 1965. Immunochemical quantitation of antigens by single radial immunodiffusion. Immunochemistry. 2: 235.

11. Cooper, M. D., H. P. Chase, J. T. Lowman, W. Krivit, and R. A. Good. 1968. Wiskott-Aldrich syndrome. An immunologic deficiency disease involving the afferent limb of immunity. Amer. J. Med. 44: 499.

12. Levin, A. S., L. E. Spitler, D. P. Stites, and H. H. Fudenberg. 1970. Wiskott-Aldrich syndrome, a genetically determined cellular immunologic deficiency: clinical and laboratory responses to therapy with transfer factor. Proc. Nat. Acad. Sci. U. S. A. 67: 821.

13. Raff, M. C., and H. H. Wortis. 1970. Thymus dependence of $\ominus$-bearing cells in the peripheral lymphoid tissues of mice. Immunology. 18: 931.

14. Oppenheim, J. J., G. N. Rogentine, and W. D. Terry. 1969. The transformation of human lymphocytes by monkey antisera to human immunoglobulins. Immunology. 16: 123.

15. Johansson, B., and E. Klein. 1970. Cell surface localized IgM-kappa immunoglobulin reactivity in a case of chronic lymphocytic leukaemia. Clin. Exp. Immunol. 6: 421.

16. Klein, E., G. Klein, J. S. Nadkarni, J. J. Nadkarni, H. Wigzell, and P. Clifford. 1968. Surface IgM-kappa specificity on a Burkitt lymphoma cell in vivo and in derived culture lines. Cancer Res. 28: 1300.

17. Pernis, B. 1971. Immunoglobulins as cell receptors. Conference on immunoglobulins. Ann. N. Y. Acad. Sci. In press.

18. Buell, D. N., and J. L. Fahey. 1969. Limited periods of gene expression in immunoglobulin-synthesizing cells. Science (Washington). 164: 1524.

19. Grey, H. M., M. Mannik, and H. G. Kunkel. 1965. Individual antigenic specificity of myeloma proteins. Characteristics and localization to subunits. J. Exp. Med. 121: 561 . 